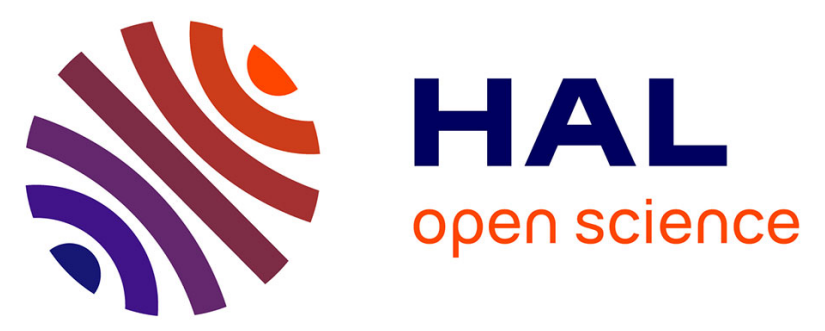

\title{
A Dissolution/Precipitation Equilibrium on the Surface of Iridium-Based Perovskites Controls Their Activity as Oxygen Evolution Reaction Catalysts in Acidic Media
}

Ronghuan Zhang, Nicolas Dubouis, Manel Ben osman, Wei Yin, Moulay

Tahar Sougrati, Daniel A. D. Corte, Domitille Giaume, Alexis Grimaud

\section{To cite this version:}

Ronghuan Zhang, Nicolas Dubouis, Manel Ben osman, Wei Yin, Moulay Tahar Sougrati, et al.. A Dissolution/Precipitation Equilibrium on the Surface of Iridium-Based Perovskites Controls Their Activity as Oxygen Evolution Reaction Catalysts in Acidic Media. Angewandte Chemie International Edition, 2019, 58 (14), pp.4571-4575. 10.1002/anie.201814075 . hal-02388351

\section{HAL Id: hal-02388351 https://hal.science/hal-02388351}

Submitted on 3 Dec 2019

HAL is a multi-disciplinary open access archive for the deposit and dissemination of scientific research documents, whether they are published or not. The documents may come from teaching and research institutions in France or abroad, or from public or private research centers.
L'archive ouverte pluridisciplinaire HAL, est destinée au dépôt et à la diffusion de documents scientifiques de niveau recherche, publiés ou non, émanant des établissements d'enseignement et de recherche français ou étrangers, des laboratoires publics ou privés. 


\title{
A dissolution/precipitation equilibrium on the surface of iridium-based perovskites controls their activity as oxygen evolution reaction catalysts in acidic media
}

\author{
Ronghuan Zhang, Nicolas Dubouis, Manel Ben Osman, Wei Yin, Moulay T. Sougrati, Daniel A. \\ D. Corte, Domitille Giaume, and Alexis Grimaud*
}

\author{
Dr. R. Zhang, N. Dubouis, W. Yin, Dr. D. Corte, Dr. A. Grimaud* \\ Chimie du Solide et de l'Energie, Collége de France, UMR 8260, 75231 Paris Cedex 05 (France) \\ E-mail: alexis.grimaud@college-de-france.fr \\ Dr. M. Ben Osman \\ Chimie de la Matière Condensée de Paris, Sorbonne Université - UPMC Univ Paris 06, Collége de France, 4 place Jussieu, 75005 Paris \\ (France) \\ Dr. M. T. Sougrati \\ ICGM, CNRS UMR5253, Université Montpellier 2, 34095 Montpellier (France) \\ Dr. D. Giaume \\ Chimie ParisTech, PSL University, CNRS, Institut de Recherche de Chimie Paris, 75005 Paris (France) \\ Dr. R. Zhang, N. Dubouis, Dr. M. Ben Osman, W. Yin, Dr. M. T. Sougrati, Dr. D. Corte, Dr. D. Giaume, Dr. A. Grimaud \\ RS2E, Réseau Français sur le Stockage Electrochimique de l'Energie, CNRS 3459 (France)
}

\begin{abstract}
Recently, $\mathrm{Ir}^{(\mathrm{V})}$-based perovskite-like materials were proposed as oxygen evolution reaction (OER) catalysts in acidic media with promising performance. However, iridium dissolution and surface reconstruction were observed, questioning the real active sites on the surface of these catalysts. In this work, $\mathrm{Sr}_{2} \mathrm{Mlr}^{(\mathrm{V})} \mathrm{O}_{6}(\mathrm{M}=\mathrm{Fe}, \mathrm{Co})$ and $\mathrm{Sr}_{2} \mathrm{Fe}_{0.5} \mathrm{Ir}_{0.5}{ }^{(\mathrm{V})} \mathrm{O}_{4}$ were explored as OER catalysts in acidic media. Their activities were observed to be roughly equal to that previously reported for $\mathrm{La}_{2} \mathrm{LillO}_{6}$ or $\mathrm{Ba}_{2} \mathrm{PrlrO}_{6}$. Coupling electrochemical measurements with iridium dissolution studies under chemical or electrochemical conditions, we show that the deposition of an $\mathrm{IrO}_{x}$ layer on the surface of these perovskites is responsible for their OER activity. Furthermore, we experimentally reconstruct the iridium Pourbaix diagram which will help guide future research in controlling the dissolution/precipitation equilibrium of iridium species for the design of better Ir-based OER catalysts.
\end{abstract}


The electrochemical production of hydrogen fuel via water splitting has long been explored as a potential way to store clean and renewable energy. The key challenge for water splitting lies in improving the efficiency of the kinetically-slow, rate-limiting oxygen evolution reaction (OER) $\left(2 \mathrm{H}_{2} \mathrm{O}=4 \mathrm{H}^{+}+\mathrm{O}_{2}+4 \mathrm{e}^{-}\right) .^{[1][2]}$ While a large variety of transition metal oxides have been studied as promising OER catalysts in alkaline media, ${ }^{[3][4][5][6]}$ the design of active and stable catalysts in acidic media has proven challenging. ${ }^{[7][8][9][10][11]}$ The few materials established as suitable OER catalysts in acidic media are mostly Ir-based metal oxides, such as rutile $\mathrm{IrO}_{2},{ }^{[12][13]}$ electrodeposited $\mathrm{IrO}_{x}{ }^{[14]}$ or more recently Ni-substituted $\mathrm{IrO}_{x^{*}}{ }^{[15][16][17]}$ Recently, Ir-based perovskites have been reported as promising candidates in acidic media. ${ }^{[18][19][20]}$ The high OER activity of these Ir-based perovskites was ascribed to the formation of electrophilic $\mathrm{O}^{(1-)}$ surface species favoring the nucleophilic attack of water. ${ }^{[1][20][21]}$ However, dissolution of iridium, alkali and/or rare earth elements in acidic electrolytes has been observed after close examinations of some Ir $^{(\mathrm{V})}$-based perovskites, such as $\mathrm{La}_{2} \mathrm{Lilr}^{(\mathrm{V})} \mathrm{O}_{6}{ }^{[20]}$ and $\mathrm{Ba}_{2} \mathrm{Prlr}^{(\mathrm{V})} \mathrm{O}_{6},{ }^{[7][19]}$ indicating their drastic structural instabilities in harsh acidic conditions. ${ }^{[12]}$ Furthermore, the presence of $\mathrm{IrO}_{2}$ nanoparticles was revealed on the surface of $\mathrm{La}_{2} \mathrm{Lil}{ }^{(\mathrm{V})} \mathrm{O}_{6}$ after cycling. ${ }^{[8]}$ Given this array of observations, a legitimate question arises upon the origin of the OER activity on the surface of these perovskites. Therefore, it is important to understand the OER mechanism of these $\mathrm{Ir}^{(\mathrm{V})}$-based perovskites as well as the effect of iridium dissolution on their catalytic behaviors, in order to improve their performances and/or guide future research in designing new active and stable OER catalysts in acidic media.

We herein investigate the catalytic behaviors of three $\operatorname{Ir}^{(\mathrm{V})}$-based OER catalysts in acidic media, $\mathrm{Sr}_{2} \mathrm{Mlr}^{(\mathrm{V})} \mathrm{O}_{6}(\mathrm{M}=\mathrm{Fe}, \mathrm{Co})$ with a double perovskite structure and $\mathrm{Sr}_{2} \mathrm{Fe}_{0.5} \mathrm{Ir}_{0.5}{ }^{(\mathrm{V})} \mathrm{O}_{4}$ with a Ruddlesden-Popper (RP) structure. Their OER activities were compared with those measured for $\mathrm{La}_{2} \mathrm{Lilr}^{(\mathrm{V})} \mathrm{O}_{6}$ and $\mathrm{Ba}_{2} \mathrm{PrIr}^{(\mathrm{V})} \mathrm{O}_{6}{ }^{\left[{ }^{[7][19]}\right.}$ Coupling electrochemical measurements with iridium dissolution studies, we propose a ubiquitous 'dissolution-electrodeposition/precipitation' mechanism for the origin of OER activities measured for these perovskites.

Structural and electronic properties of $\mathrm{Sr}_{2} \mathrm{Felr}^{(\mathrm{V})} \mathrm{O}_{6}, \mathrm{Sr}_{2} \mathrm{Fe}_{0.5} \mathrm{Ir}_{0.5}{ }^{(\mathrm{V})} \mathrm{O}_{4}$ and $\mathrm{Sr}_{2} \mathrm{Colr}^{(\mathrm{V})} \mathrm{O}_{6}$ are shown in the supporting information (Figures S1-S4) and their catalytic behaviors in Figures 1a-1c. $\mathrm{Sr}_{2} \mathrm{Colr}^{(\mathrm{V})} \mathrm{O}_{6}$ exhibits an enhanced OER activity compared to commercial micron-size $\operatorname{IrO}_{2}(\sim 3$ fold) (Figure 1d) and a stable electrochemical performance with an overpotential of $\sim 330 \mathrm{mV}$ at 10 $\mathrm{mA} / \mathrm{cm}^{2}{ }_{\text {oxide }}$ for $24 \mathrm{~h}$ (Table S2, Figure S10). Unlike $\mathrm{Sr}_{2} \mathrm{Colr}^{(\mathrm{V})} \mathrm{O}_{6}$, the OER activity measured for $\mathrm{Sr}_{2} \mathrm{Felr}^{(\mathrm{V})} \mathrm{O}_{6}$ was initially low $\left(1^{\text {th }}\right.$ cycle), but gradually increased within 50 cycles to an activity comparable to that of $\mathrm{Sr}_{2} \mathrm{Colr}^{(\mathrm{V})} \mathrm{O}_{6}$ (Figure 1b). The catalytic behavior of $\mathrm{Sr}_{2} \mathrm{Fe}_{0.5} \mathrm{Ir}_{0.5}{ }^{(\mathrm{V})} \mathrm{O}_{4}$ with a RP structure is surprisingly similar to that of $\mathrm{Sr}_{2} \mathrm{Felr}^{(\mathrm{V})} \mathrm{O}_{6}$ perovskite regardless of apparent differences of their crystal structures (inset of Figure 1). More interestingly, the OER activities recorded for $\mathrm{Sr}_{2} \mathrm{Felr}^{(\mathrm{V})} \mathrm{O}_{6}, \mathrm{Sr}_{2} \mathrm{Fe}_{0.5} \mathrm{Ir}_{0.5}{ }^{(\mathrm{V})} \mathrm{O}_{4}$ and $\mathrm{Sr}_{2} \mathrm{Colr}^{(\mathrm{V})} \mathrm{O}_{6}$ after the activation step (50 cycles) are roughly equal to those of previously reported $\mathrm{Ir}^{(\mathrm{V})}$-based perovskites $\mathrm{Ba}_{2} \mathrm{LnIr}^{(\mathrm{V})} \mathrm{O}_{6}$ and $\mathrm{La}_{2} \mathrm{Lilr}^{(\mathrm{V})} \mathrm{O}_{6}$ when normalized by their BET surface areas (Figure 1d). ${ }^{[19][20]}$ These observations suggest that the final OER activity of $\mathrm{Ir}^{(\mathrm{V})}$-based perovskite-like catalysts is independent of the crystal structure as well as the composition of the catalyst. This odd phenomenon drove us to reconsider the nature of the catalytic active sites for these $\mathrm{Ir}^{(\mathrm{V})}$-based perovskites.

As mentioned earlier, dissolution of iridium has been previously observed for Ir-based perovskites in acidic media. ${ }^{[7][8][9]}$ As a key active element in all $\mathrm{Ir}^{(\mathrm{V})}$-based catalysts, the loss of iridium from the bulk as well as the presence of leached species in electrolytes should affect their catalytic behaviors. In order to better understand the impact of iridium dissolution, we considered an extreme case where samples of $\mathrm{Ir}^{(\mathrm{V})}$-based perovskites were deliberately soaked to dissolve in $0.1 \mathrm{M} \mathrm{HCIO}_{4}(\mathrm{SI}$. 4). The resulting solutions all exhibit a similar purple-pink color, corresponding to a soluble species with a common broad absorption peak at $\sim 520$ $\mathrm{nm}$ in their UV-Vis spectra (Figure 2a). Amorphous $\mathrm{IrO}_{2}$ precipitants were observed when this purple-pink solution was heated up (Figure S5). This together with the UV-Vis further confirms that all of these $\mathrm{Ir}^{(\mathrm{V})}$-based perovskites partially dissolve in the acid to form a common purple-pink solution containing soluble iridium species. 
a)

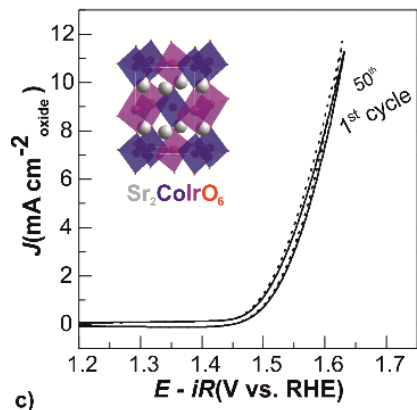

c)

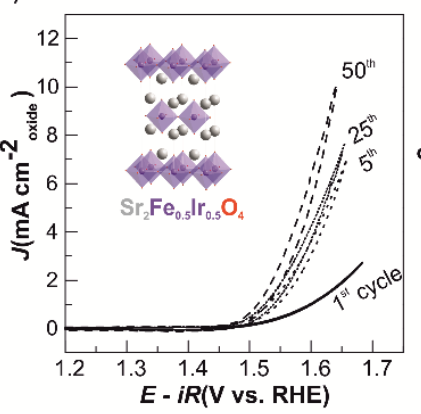

b)

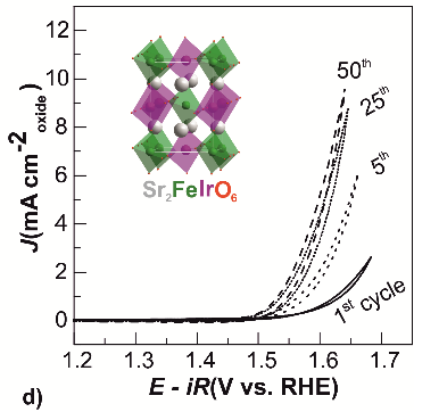

d)

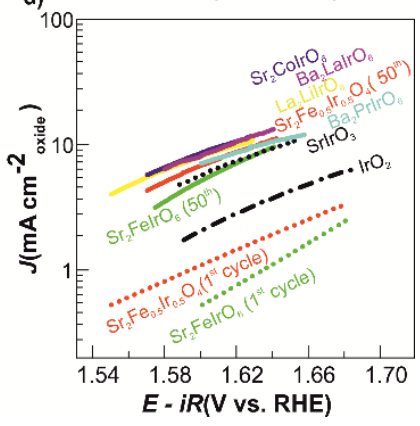

Figure 1. Structures (inset) of and CVs recorded for a) $\mathrm{Sr}_{2} \mathrm{Colr}^{(\mathrm{V})} \mathrm{O}_{6}$, b) $\mathrm{Sr}_{2} \mathrm{Felr}^{(\mathrm{V})} \mathrm{O}_{6}$ and c) $\mathrm{Sr}_{2} \mathrm{Fe}_{0.5} \mathrm{Ir}_{0.5}{ }^{(\mathrm{V})} \mathrm{O}_{4}$ in $0.1 \mathrm{M} \mathrm{HClO} \mathrm{H}_{4}$ with a scan rate of $10 \mathrm{mV} / \mathrm{s}$. d) Tafel plots for selected catalysts scaled with their BET surface areas (Table S2).

This purple-pink iridium solution was then used as 'Ir-containing electrolyte' to investigate its contribution in catalyzing the OER using a blank glassy carbon electrode (GCE) (Figure 2c). The results were compared with a control experiment conducted by cycling a blank GCE in fresh electrolyte. We observed that the GCE cycled in the 'Ir-containing electrolyte' gradually became OER active along cycling, while that cycled in fresh electrolyte exhibited negligible OER activity (Figure 2b). Moreover, the activation feature $\left(1^{\text {st }}\right.$ to $50^{\text {th }}$ cycle) observed with the GCE cycling in the 'Ir-containing electrolyte' is strikingly similar to that recorded for $\mathrm{Sr}_{2} \mathrm{Felr}^{(\mathrm{V})} \mathrm{O}_{6}$ and $\mathrm{Sr}_{2} \mathrm{Fe}_{0.5} \mathrm{Ir}_{0.5}{ }^{(\mathrm{V})} \mathrm{O}_{4}$ (Figure 1), suggesting a similar catalytic mechanism. After electrochemical measurements in the 'Ircontaining electrolyte', some traces of blue-black particles were observed on the surface of the GCE. These particles were confirmed to contain iridium by energy-dispersive X-ray (EDX) analysis (Figure S6). Therefore, it's reasonable to conclude that the OER-active species are $\mathrm{IrO}_{x}$ (or hydrated $\mathrm{IrO}_{x} \cdot \mathrm{mH}_{2} \mathrm{O}$ ) gradually electrodeposited during the cycling process onto the surface of the GCE from the purple-pink Ir-containing electrolyte. It's worth nothing that not all soluble iridium species (e.g. $\left.\mathrm{K}_{2} \mid \mathrm{rCl} \mathrm{I}_{6}\right) \mathrm{could}_{\mathrm{l}} \mathrm{deposit}$ into $\mathrm{IrO}_{x}$. This experiment demonstrates that the leached iridium species in the electrolyte can actually return to the surface of the catalyst and affect its OER activity. Careful examination of the pseudocapacitive region of the CV reveals a reversible feature at $\sim$ $0.92 \mathrm{~V}$ vs. RHE (Figure 2b), agreeing with that observed during electrodeposition of hydrous iridium oxide film from soluble precursors $^{[22][23][24][25]}$. The small peak separation $(\sim 23 \mathrm{mV})$ suggests the formation of a non-diffusional, surface-bound species, which is consistent with the deposition/dissolution of $\mathrm{IrO}_{x} \cdot \mathrm{mH}_{2} \mathrm{O}$ in our experiment. The growing intensity of this reversible feature as well as the expansion of the pseudocapacitive region along cycling (Figure $2 \mathrm{~b}$ ) suggests an increasing amount of active Ir $_{x}$ deposited on the electrode, leading to the enhanced OER activity. 
a)

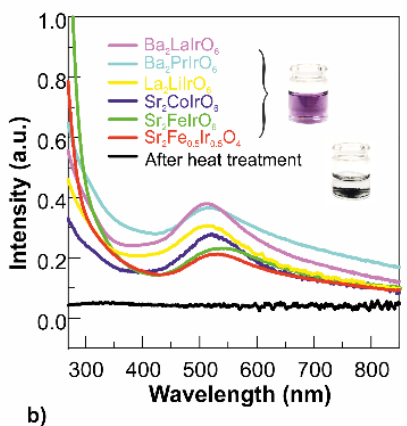

b)

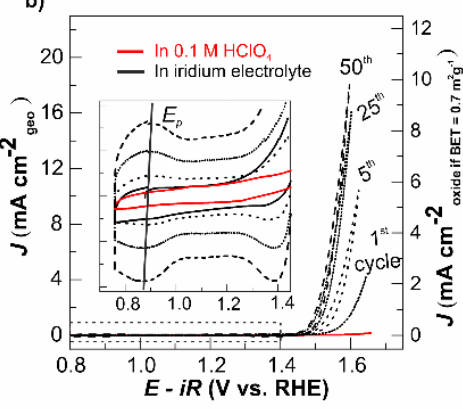

c)

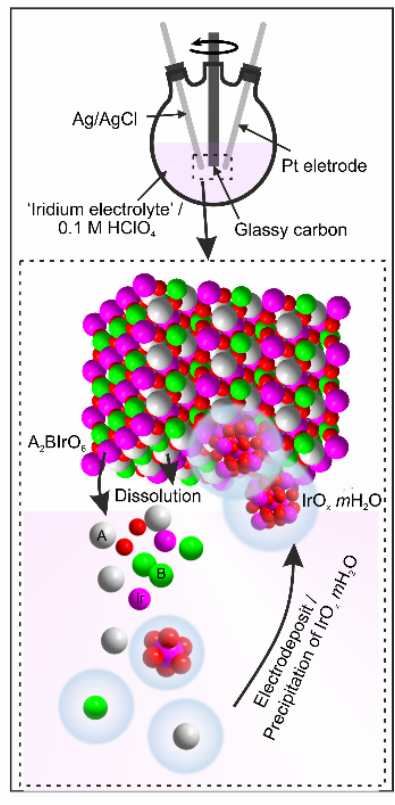

Figure 2. a) UV-Vis spectra recorded from purple-pink solutions prepared by dissolving $\mathrm{Ir}^{(\mathrm{V})}$-based perovskites (SI. 4), and the solution after heat treatment in a microwave. b) The CVs recorded for the blank GCE in $0.1 \mathrm{M} \mathrm{HClO}_{4}$ or Ir-containing electrolyte (the right y-axis is scaled assuming a normal loading of $10 \mu \mathrm{g}$ catalysts with $\mathrm{BET}=0.7 \mathrm{~m}^{2} / \mathrm{g}$ as that of $\mathrm{Sr}_{2} \mathrm{FelrO}_{6}$ ); Inset is the zoomed-in pseudocapacitive region. c) Experimental set-ups and the proposed OER catalytic mechanism involving the 'dissolution-electrodeposition' of iridium species.

The similarities between the OER behaviors recorded for $\mathrm{Sr}_{2} \mathrm{Fe} \mathrm{Ir}^{(\mathrm{V})} \mathrm{O}_{6}$ and $\mathrm{Sr}_{2} \mathrm{Fe}_{0.5} \mathrm{Ir}_{0.5}{ }^{(\mathrm{V})} \mathrm{O}_{4}$ and that recorded for a blank GCE in the 'Ir-containing electrolyte' suggests that their OER catalytic mechanism involves the 'dissolution-electrodeposition' of iridium species as depicted in Figure 2c. In this mechanism, the catalyst suffers leaching of iridium from its bulk structure when soaked in acidic electrolytes and subsequently the leached iridium species are electrochemically deposited as $\operatorname{IrO} \mathrm{O}_{x} \cdot \mathrm{mH}_{2} \mathrm{O}$ onto the surface of the catalyst to give rise to the OER activity. The electrodeposition of $\mathrm{IrO}_{x} \cdot m \mathrm{H}_{2} \mathrm{O}$ occurs when the applied external potential exceeds its 'precipitation potential' that we estimate from our CV results to be $E_{p-r o x} \approx 0.92 \mathrm{~V}$ vs. RHE. Therefore, the OER activity of these perovskites is strongly correlated with the surface morphology and the amount of deposited $\operatorname{IrO}_{x} \cdot m \mathrm{H}_{2} \mathrm{O}$, but independent of the actual structure or composition of these perovskites. This conclusion is consistent with the ex-situ X-ray absorption measurements at $\mathrm{Ir} \mathrm{L}_{3}$-edge where a reduction of the $\mathrm{Ir}$ oxidation state (formation of $\operatorname{~Ir~}^{(\mathrm{III/V})} \mathrm{O}_{x}$ ) was observed for both $\mathrm{Sr}_{2} \mathrm{Fe} \mathrm{Ir}^{(\mathrm{V})} \mathrm{O}_{6}$ and $\mathrm{Sr}_{2} \mathrm{Colr}^{(\mathrm{V})} \mathrm{O}_{6}$ after CV measurements (Figure S7).

To probe the 'dissolution-electrodeposition' of iridium species, an elemental analysis by inductively coupled plasma optical emission spectrometry (ICP-OES) was conducted to trace the dissolution of iridium upon time (Figure 3b, Figures S11 and S12). Two parallel experiments were carried out for each catalyst: one with the catalyst operated at $1 \mathrm{~mA} / \mathrm{cm}^{2}{ }_{\text {oxide }}$ to investigate the iridium leaching under electrochemical OER conditions (Ec), and the other with the oxide solely soaked in the electrolyte without applied currents to investigate the leaching process under chemical conditions (C). For $\mathrm{Sr}_{2} \mathrm{Felr}^{(\mathrm{V})} \mathrm{O}_{6}$ and $\mathrm{Sr}_{2} \mathrm{Fe}_{0.5} \mathrm{Ir}_{0.5}{ }^{(\mathrm{V})} \mathrm{O}_{4}$, an increasing amount of leached iridium was detected within a soaking time of 24 hours (C) (Figure 3b), in good agreement with the UV-Vis. Interestingly, the concentration of leached iridium in the electrolyte operated under electrochemical conditions (Ec) is considerably less than that under chemical conditions $(C)$, suggesting an electrodeposition of iridium species from the electrolyte onto the surface of the electrode in the former case. This result is in stark contrast to that of $\mathrm{Sr}_{2} \mathrm{Colr}^{(\mathrm{V})} \mathrm{O}_{6}$ where similar iridium dissolution behaviors were observed under electrochemical $(\mathrm{Ec})$ and chemical $(\mathrm{C})$ conditions. 
a)

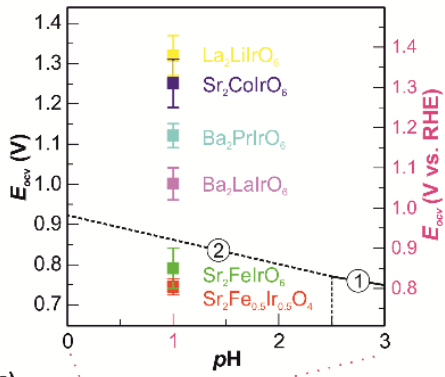

b)

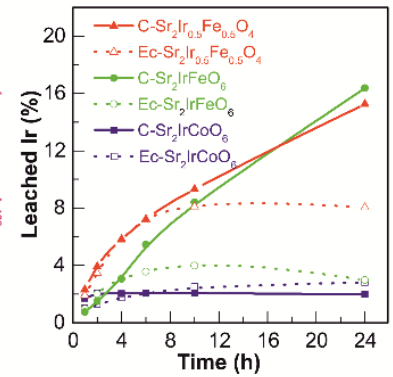

c)

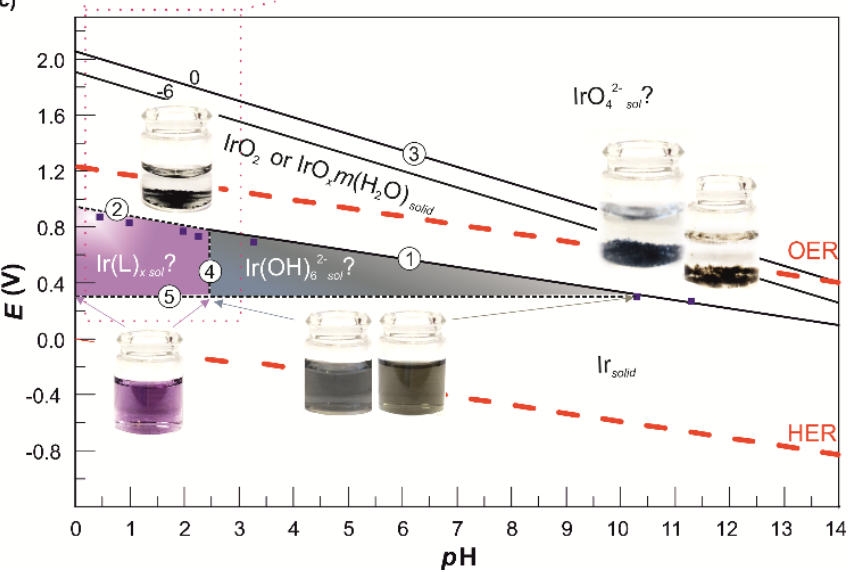

Figure 3. a) $E_{o c v}$ measured for $\mathrm{Ir}^{(\mathrm{V})}$-based perovskites. b) The percentage of leached iridium detected by ICP (error bar: $5 \sim 10 \%$ ) under chemical (solely soaking) or electrochemical conditions $\left(1 \mathrm{~mA} / \mathrm{cm}^{2}\right)$. Leached percentage $=$ (leached mass of Ir) / (starting mass of Ir) ${ }^{*} 100 \%$. $\left.\mathrm{c}\right)$ Iridium $\mathrm{E}_{\mathrm{H}}-\mathrm{pH}$ diagram.

When iridium dissolves off the structure of the perovskite, a solution containing soluble iridium species is formed. The precipitation of these soluble iridium species into the OER active $\mathrm{IrO}_{x} \cdot \mathrm{mH}_{2} \mathrm{O}$ particles on surface of the GCE should be potential dependent and follow the Pourbaix diagram of iridium. For $\mathrm{Sr}_{2} \mathrm{Felr}^{(\mathrm{V})} \mathrm{O}_{6}$, and $\mathrm{Sr}_{2} \mathrm{Fe}_{0.5} \mathrm{Ir}_{0.5}{ }^{(\mathrm{V})} \mathrm{O}_{4}$, their open circuit potentials (Figure 3a, $\mathrm{E}_{\mathrm{ocv}} \approx 0.85 \mathrm{~V}$ and $0.80 \mathrm{~V}$ vs. RHE respectively) were measured to sit below the 'precipitation potential' ( $E_{\text {p-rrox }} \approx 0.92 \mathrm{~V}$ vs. RHE) of $\mathrm{IrO}_{x} \cdot m \mathrm{H}_{2} \mathrm{O}$. In contrast, the open circuit potential of $\mathrm{Sr}_{2} \mathrm{Colr}^{(\mathrm{V})} \mathrm{O}_{6}\left(\mathrm{E}_{\mathrm{ocv}} \approx 1.31 \mathrm{~V}\right.$ vs. RHE) was measured to lie above $E_{p-\text { Irox }}$. Therefore, the precipitation of $\mathrm{IrO}_{x} \cdot \mathrm{mH}_{2} \mathrm{O}$ occurs without any applied potentials when soaking $\mathrm{Sr}_{2} \mathrm{Colr}^{(\mathrm{V})} \mathrm{O}_{6}$ in the acidic electrolyte. This explains why the iridium concentration detected in the electrolyte under chemical conditions $(\mathrm{C})$ was found similar to that under electrochemical conditions (Ec) for $\mathrm{Sr}_{2} \mathrm{Colr}^{(\mathrm{V})} \mathrm{O}_{6}$, while much greater for $\mathrm{Sr}_{2} \mathrm{Felr}^{(\mathrm{V})} \mathrm{O}_{6}$ and $\mathrm{Sr}_{2} \mathrm{Fe}_{0.5} \mathrm{Ir}_{0.5}{ }^{(\mathrm{V})} \mathrm{O}_{4}$ (Figure 3b). The formation of Ir rich surface under Ec condition was also confirmed by the disappearance of Co on the surface by XAS (Figure S13). The precipitation of iridium species under both $\mathrm{Ec}$ and $\mathrm{C}$ conditions for $\mathrm{Sr}_{2} \mathrm{Colr}^{(\mathrm{V})} \mathrm{O}_{6}$ was further confirmed by EDX analysis where iridium rich particles were observed after treatment under both conditions (Figure S14).

All these observations suggest that the OER activity of $\operatorname{~rr}^{(\mathrm{V})}$-based perovskites is eventually confined by the potential/pH $\left(\mathrm{E}_{\mathrm{H}^{-}}\right.$ $\mathrm{pH})$ domain where $\mathrm{IrO}_{x} \cdot \mathrm{mH}_{2} \mathrm{O}$ species are stable. Therefore, in order to ater predict the catalytic behavior of other $\operatorname{Ir}^{(\mathrm{V})}$-based perovskite-like catalysts, we reconstructed the $\mathrm{E}_{\mathrm{H}}-\mathrm{pH}$ diagram of iridium (Figure 3c, and detailed in SI. 9) using our experimental results as well as the equations previously established by Pourbaix ${ }^{[26]}$. The $E_{p-\text { rox }}$ was used as the critical potential distinguishing soluble iridium species out of solid $\mathrm{IrO}_{x} \cdot \mathrm{mH}_{2} \mathrm{O}$ or $\mathrm{IrO}_{2}$. $\mathrm{Ir}^{(\mathrm{V})}$-based perovskites such as $\mathrm{Sr}_{2} \mathrm{Colr}^{(\mathrm{V})} \mathrm{O}_{6}, \mathrm{La}_{2} \mathrm{Lilr}^{(\mathrm{V})} \mathrm{O}_{6}, \mathrm{Ba}_{2} \mathrm{PrIr}^{(\mathrm{V})} \mathrm{O}_{6}$ and $\mathrm{Ba}_{2} \mathrm{Lalr}^{(\mathrm{V})} \mathrm{O}_{6}$ were measured to possess an open circuit potential higher than $E_{p-\text { rrox }}$, (Figure $3 a$ ). At low pH, iridium species thus precipitate into OER-active $\mathrm{IrO}_{x} \cdot \mathrm{mH}_{2} \mathrm{O}$ at the open circuit potentials for these perovskites and their OER activities most likely originate from $\mathrm{IrO}_{x} \cdot \mathrm{mH}_{2} \mathrm{O}$ species precipitated at $\mathrm{E}_{\mathrm{Ocv}}$. This assumption is further supported by the stable OER activities measured for these catalysts from the $1^{\text {st }}$ to the $50^{\text {th }}$ cycle. In contrast, for $\mathrm{Sr}_{2} \mathrm{Felr}^{(\mathrm{V})} \mathrm{O}_{6}$ and $\mathrm{Sr}_{2} \mathrm{Fe}_{0.5} \mathrm{Ir}_{0.5}{ }^{(\mathrm{V})} \mathrm{O}_{4}$ with $\mathrm{E}_{\text {ocv }}<E_{p-\text {-rrox }}$, the amount of precipitated OER-active $\mathrm{IrO}_{x} \cdot \mathrm{mH}_{2} \mathrm{O}$ is initially $\approx 0$ and the initial OER activity $\left(1^{\text {st }}\right.$ cycle) is thus low, revealing the intrinsic inactive feature of these $\mathrm{Ir}^{(\mathrm{V})}$-based perovskites. ${ }^{[20]}$ Upon cycling, the OER-active $\operatorname{IrO}_{x} \cdot \mathrm{mH}_{2} \mathrm{O}$ is formed on the surface of $\mathrm{Sr}_{2} \mathrm{Felr}^{(\mathrm{V})} \mathrm{O}_{6}$ and $\mathrm{Sr}_{2} \mathrm{Fe}_{0.5} \mathrm{Ir}_{0.5}{ }^{(\mathrm{V})} \mathrm{O}_{4}$ via an electrodeposition process triggered during CV measurements from 1.1 to $1.7 \mathrm{~V}$ vs $\mathrm{RHE}$ (potential $>E_{p-r r o x}$ ). Given that the amount of electrodeposited $\mathrm{IrO}_{x} \cdot \mathrm{mH}_{2} \mathrm{O}$ is correlated to the operation time at a potential above $E_{p-\text { rrox }}$, the measured OER activity of $\mathrm{Sr}_{2} \mathrm{Felr}^{(\mathrm{V})} \mathrm{O}_{6}$ and $\mathrm{Sr}_{2} \mathrm{Fe}_{0.5} \mathrm{Ir}_{0.5}{ }^{(\mathrm{V})} \mathrm{O}_{4}$ is expected to increase gradually along cycling before being confined by the intrinsic activity of $\mathrm{IrO}_{x} \cdot \mathrm{mH}_{2} \mathrm{O}$ and the available oxide surfaces onto which it deposits (estimated to be the initial BET surface area of the perovskites). This is consistent with our experimental results that the OER activities after several cycles are similar (normalized by 
BET) for every $\mathrm{Ir}^{(\mathrm{V})}$-based perovskite regardless of their crystal structures or chemical compositions (Figure 1d). One could argue that a slower electrochemical leaching rate of Fe compared to Co (while Ir corrodes slow) could also explain different activation behaviors as observed for Ir-Fe and Ir-Co catalysts. However, Fe corrodes not slower than Co, but even faster in $\mathrm{Sr}_{2} \mathrm{Fe}_{0.5} \mathrm{Ir}_{0.5}{ }^{(\mathrm{V})} \mathrm{O}_{4}$ (Figure S15). In addition, to further examine the dissolution-deposition mechanism, a potential of $1.30 \mathrm{~V}$ vs. RHE (corresponding to the $\mathrm{E}_{\mathrm{ocv}}$ of $\left.\mathrm{Sr}_{2} \mid \mathrm{rCoO}_{6}\right)$ was applied on $\mathrm{Sr}_{2} \mathrm{lrFeO}$, resulting in an enhanced OER activity (1 ${ }^{\text {st }}$ cycle) in the following CVs due to increased deposition of $\mathrm{IrO}_{x}$ at a potential $>E_{p-\text {-rox }}$ (Figure S16). These results further support the dissolution-deposit mechanism of Ir species.

We then investigated the evolution of the purple-pink Ir-containing solution as a function of $\mathrm{pH}$ by slowly adding in $1 \mathrm{M} \mathrm{NaOH}$

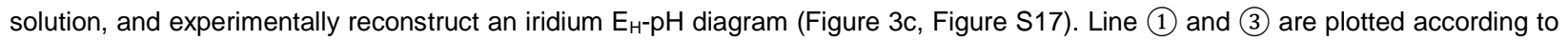
the equilibrium of $\mathrm{Ir} / \mathrm{IrO}_{2}\left(\mathrm{Ir}+2 \mathrm{H}_{2} \mathrm{O}=\mathrm{IrO}_{2}+4 \mathrm{H}^{+}+4 \mathrm{e}^{-}\right)$and $\mathrm{IrO}_{2} / \mathrm{IrO}_{4}{ }^{2-}\left(\mathrm{IrO}_{2}+2 \mathrm{H}_{2} \mathrm{O}=\mathrm{IrO}_{4}{ }^{2-}+4 \mathrm{H}^{+}+2 \mathrm{e}^{-}\right)$, respectively. Dashed line (2) is plotted as the equilibrium between soluble iridium species $\operatorname{Ir}(\mathrm{L})_{x}$ and $\operatorname{IrO}_{2}$ using $E_{p-\text { Irox }}$ estimated earlier. When increasing the $\mathrm{pH}$ above $\sim 2.5$, a color change from pink to olive-green or blue was observed (dashed line (4)). This color change matches with the shifting of the UV-Vis absorption peak to $~ 580 \mathrm{~nm}$ (Figure S18), which is a characteristic absorption for $\operatorname{Ir}^{(\mathrm{IV})}$ species. ${ }^{[17][27]} \mathrm{This}^{\mathrm{i}}$ change in color and in UV-Vis spectrum is possibly resulting from the replacement with $\mathrm{H}_{2} \mathrm{O}$ or $\mathrm{OH}^{-}$around iridium to form $\operatorname{Ir}(\mathrm{OH})_{6}{ }^{2-}$ or $\operatorname{Ir}(\mathrm{OH})_{2}\left(\mathrm{ClO}_{4}\right)_{4}{ }^{2-} \cdot{ }^{[27][28]}$ Study of the precise nature of these iridium species is challenging. ${ }^{[28]}$ Fractions of $-\mathrm{Ir}-\mathrm{O}-\mathrm{or}-\mathrm{Ir}-\mathrm{OH}-$ might be maintained during dissolution of $\mathrm{Ir}^{(\mathrm{V})}$-perovskites, which facilitates the precipitation of OER-active $\mathrm{IrO}_{x}$ at potential above $E_{p}$. IrOx (Figure 2c). Finally, adding more $\mathrm{NaOH}$, the $\mathrm{pH}$ quickly increased and blue or olive-brown precipitates started to form. Filtering out the precipitates resulted in a colorless solution and disappearance of the UV-Vis absorption at $\sim 580 \mathrm{~nm}$, suggesting the precipitation of iridium species.

Our study highlights that the stability of $\operatorname{~Ir~}^{(\mathrm{V})}$-based perovskite-like catalysts is limited in acidic media by the potentialdependent dissolution/precipitation equilibrium of iridium species. Though kinetics for iridium dissolution might be structuredependent, this dissolution for perovskites is still extremely difficult to avoid owing to the heavy leaching of A-site alkali and/or rare earth elements in acidic electrolytes. Overall, even though the initial OER activity can reflect the intrinsic properties of Ir $^{(\mathrm{V})}$-based perovskites, the activity is eventually dominated by $\mathrm{IrO}_{x} \cdot \mathrm{mH}_{2} \mathrm{O}$ which is the thermodynamically stable phase formed on their surface. Finally, our study reveals that the precipitation of $\mathrm{IrO}_{x} \cdot \mathrm{mH}_{2} \mathrm{O}$ is dependent on the electronic structure of the catalyst since it is controlled by its open circuit potential. This finding offers a new avenue to design highly active OER surfaces in acidic media, complementing previous works where the dissolution/precipitation rates were controlled by change of the morphology (change in local concentration). ${ }^{[29]}$

\section{Acknowledgements}

A.G. and R.Z. acknowledge financial support from the ANR MIDWAY (Project ID: ANR-17-CE05-0008). We thank the Diamond Light Source of the award of beam time as part of the Energy Materials Block Allocation Group SP14239. We thank A. V. Chadwick and G. Cibin for assistance with XAS measurements. Use of the Advanced Photon Source at Argonne National Laboratory was supported by the U.S. Department of Energy, Office of Science, Office of Basic Energy Sciences, under Contract No. DE-AC02-06CH11357.

Keywords: perovskite • oxygen evolution reaction • iridium dissolution • Pourbaix diagram

[1] E. Fabbri, A. Habereder, K. Waltar, R. Kötz, T. J. Schmidt, Catal. Sci. Technol. 2014, 4, 3800-3821.

[2] H. Dau, C. Limberg, T. Reier, M. Risch, S. Roggan, P. Strasser, ChemCatChem 2010, 2, 724-761.

[3] E. Fabbri, M. Nachtegaal, T. Binninger, X. Cheng, B. J. Kim, J. Durst, F. Bozza, T. Graule, R. Schäublin, L. Wiles, et al., Nat. Mater. 2017, $16,925-931$.

[4] W. T. Hong, M. Risch, K. A. Stoerzinger, A. Grimaud, J. Suntivich, Y. Shao-Horn, Energy Environ. Sci. 2015,8 , $1404-1427$.

[5] J. Suntivich, K. J. May, H. A. Gasteiger, J. B. Goodenough, Y. Shao-Horn, Science (80-. ). 2011, 334, $1383-1385$.

[6] J. T. Mefford, X. Rong, A. M. Abakumov, W. G. Hardin, S. Dai, A. M. Kolpak, K. P. Johnston, K. J. Stevenson, Nat. Commun. 2016, 7, 11053.

[7] S. Geiger, O. Kasian, M. Ledendecker, E. Pizzutilo, A. M. Mingers, W. T. Fu, O. Diaz-Morales, Z. Li, T. Oellers, L. Fruchter, et al., Nat. Catal. 2018, 1, 508-515.

[8] S. Cherevko, A. R. Zeradjanin, A. A. Topalov, N. Kulyk, I. Katsounaros, K. J. J. Mayrhofer, ChemCatChem 2014, 6, $2219-2223$.

[9] O. Kasian, J. P. Grote, S. Geiger, S. Cherevko, K. J. J. Mayrhofer, Angew. Chemie - Int. Ed. 2018, 57, $2488-2491$.

[10] V. A. Saveleva, L. Wang, D. Teschner, T. Jones, A. S. Gago, K. A. Friedrich, S. Zafeiratos, R. Schlögl, E. R. Savinova, J. Phys. Chem. Lett. 2018, 9, 3154-3160.

[11] V. Pfeifer, T. E. Jones, J. J. Velasco Vélez, R. Arrigo, S. Piccinin, M. Hävecker, A. Knop-Gericke, R. Schlögl, Chem. Sci. 2017, 8, 2143- 
2149.

[12] S. Cherevko, S. Geiger, O. Kasian, N. Kulyk, J. P. Grote, A. Savan, B. R. Shrestha, S. Merzlikin, B. Breitbach, A. Ludwig, et al., Catal. Today 2016, 262, 170-180.

[13] Y. Lee, J. Suntivich, K. J. May, E. E. Perry, Y. Shao-Horn, J. Phys. Chem. Lett. 2012, 3, 399-404.

[14] D. F. Abbott, D. Lebedev, K. Waltar, M. Povia, M. Nachtegaal, E. Fabbri, C. Copéret, T. J. Schmidt, Chem. Mater. 2016, $28,6591-6604$.

[15] H. N. Nong, H. S. Oh, T. Reier, E. Willinger, M. G. Willinger, V. Petkov, D. Teschner, P. Strasser, Angew. Chemie - Int. Ed. 2015, 54, 29752979.

[16] H. N. Nong, T. Reier, H.-S. Oh, M. Gliech, P. Paciok, T. H. T. Vu, D. Teschner, M. Heggen, V. Petkov, R. Schlögl, et al., Nat. Catal. 2018, 1, 841-851.

[17] M. Yagi, E. Tomita, T. Kuwabara, J. Electroanal. Chem. 2005, 579, 83-88.

[18] L. C. Seitz, C. F. Dickens, K. Nishio, Y. Hikita, J. Montoya, A. Doyle, C. Kirk, A. Vojvodic, H. Y. Hwang, J. K. Norskov, et al., $2016,353$.

[19] O. Diaz-Morales, S. Raaijman, R. Kortlever, P. J. Kooyman, T. Wezendonk, J. Gascon, W. T. Fu, M. T. M. Koper, Nat. Commun. 2016, 7, 12363.

[20] A. Grimaud, A. Demortière, M. Saubanère, W. Dachraoui, M. Duchamp, M.-L. Doublet, J.-M. Tarascon, Nat. Energy 2016, $2,16189$.

[21] V. Pfeifer, T. E. Jones, J. J. Velasco Vélez, C. Massué, M. T. Greiner, R. Arrigo, D. Teschner, F. Girgsdies, M. Scherzer, J. Allan, et al., Phys. Chem. Chem. Phys. 2016, 18, 2292-2296.

[22] S. A. M. Marzouk, Anal. Chem. 2003, 75, 1258-1266.

[23] J. D. Blakemore, N. D. Schley, M. N. Kushner-Lenhoff, A. M. Winter, F. D'Souza, R. H. Crabtree, G. W. Brudvig, Inorg. Chem. 2012, 51, 7749-7763.

[24] J. D. Blakemore, N. D. Schley, G. W. Olack, C. D. Incarvito, G. W. Brudvig, R. H. Crabtree, Chem. Sci. 2011, 2, 94-98.

[25] Y. Mo, I. C. Stefan, W. Bin Cai, J. Dong, P. Carey, D. A. Scherson, J. Phys. Chem. B 2002, 106, 3681-3686.

[26] M. J. N. Pourbaix, J. Van Muylder, N. De Zoubov, Platin. Met. Rev. 1959, 47-53.

[27] J. E. Baur, T. W. Spaine, J. Electroanal. Chem. 1998, 443, 208-216.

[28] D. A. Fine, J. Inorg. Nucl. Chem. 1970, 32, 2731-2742.

[29] S. H. Chang, N. Danilovic, K. C. Chang, R. Subbaraman, A. P. Paulikas, D. D. Fong, M. J. Highland, P. M. Baldo, V. R. Stamenkovic, J. W. Freeland, et al., Nat. Commun. 2014, 5, 1-9. 